\title{
Cikkismertetés: A háztartási káosz (családi szervezetlenség), mint a gyermekkori fejlődési zavarok kockázati tényezője a népegészségügyi szakemberek figyelmének látóterében
}

\author{
Article review: Household chaos: a risk factor for adverse child outcomes \\ gains attention in public health
}

Ismertető: $\quad$ Asbóth Katalin $\square$

Heim Pál Országos Gyermekgyógyászati Intézet, Budapest

Ismertetett cikk: Marsh, S., Dobson, R. \& Maddison, R. The relationship between household chaos and child, parent, and family outcomes: a systematic scoping review. BMC Public Health 2020;20:513 https://doi.org/10.1186/s12889-020-08587-8, Emond J.A. Household chaos: a risk factor for adverse child outcomes gains attention in public health BMC Public Health; 2020;20:596

Beküldve: $\quad$ 2020. 06. 04.

doi: $\quad$ 10.24365/ef.v61i3.605

Kulcsszavak: szervezetlenség; gyermek - jóllét; társas - érzelmi és viselkedés zavarok; biomarkerek

Keywords: disorganization; child well-being; socio-emotional and behavioural problems; biomarkers

A fejlődéslélektan már korábban is vizsgálta az ún. "családi káosz" (szervezetlenség, zűrzavar, összevisszaság) tartós és nagyobb fokú jelenlétének hatását a gyermekek fejlődésére, jóllétére, szerepét a tanulási és viselkedészavarokban, hátrányos és kedvezőtlen fejlődésben.

Újabban a közegészségügy figyelmét is felkeltette a téma. Jelen ismertető egy szisztematikus áttekintő vizsgálatra hívja fel a figyelmet, melyet Marsh és munkatársai 112 tanulmány feldolgozásával készítettek a "háztartási káosz" gyermekekre, szülőkre és a családi múködés egészére gyakorolt hatásáról.

A tanulmány kiemeli a gyermekek egészségére gyakorolt káros hatásokat is, melyek a "háztartási káosz" együttes hatásaként keletkeznek pl. a gyermek alvási, étkezési szokásaiban, viselkedésében és súlygyarapodásában. A "háztartási káosz" összefüggésbe hozható a gyermek- és fiatalkori asztma elégtelen kontrolljával, a nem megfelelő diabetes kontrollal, és az elhízással is. A tanulmány kitér még a gyermekek képernyő- és médiahasználatára, mely még különösen kevéssé vizsgált terület ezzel a problémával kapcsolatban.

A vizsgált cikkek közel 54\%-a keresztmetszeti, 44\%a pedig longitudinális vizsgálatok adatait dolgozza fel, kettő experimentális (kísérleti) vizsgálat volt, egy pedig esettanulmányra épül. A szerzők olyan validált skálákat alkalmaztak, mint pl. Confusion, Matheny-féle Hubbub and Order Skála stb. Nyolc tanulmány biomarkerek mérését is tartalmazza (pl. kortizol szintet). 


\section{TANULSÁGOK A HAZAI SZAKEMBEREK SZÁMÁRA}

A "családi káosz" fogalmával, jelenségével a hazai szakembereknek is fontos foglalkozniuk, hiszen a gyermekek fejlődészavara, valamint egyes betegségek kapcsán komoly rizikótényezőt jelent. Mivel sok tényezőből tevődik össze, hasznos a szakmaközi párbeszéd, egyeztetett intervenció kialakítása. A hazai jógyakorlatok közül a szülői szerepre való felkészítés, annak támogatása segíthet a megelőzésben és a korrekcióban. 